\title{
Bilişim teknolojileri kullanımının işletmelerde bilgi yönetimi süreci üzerine etkisi
}

\author{
Effect of the use of information technologies on the information \\ management process in the business
}

Bülent Akkoyun ${ }^{1}$

${ }^{1}$ Dr. Öğr.Üyesi, Malatya Turgut Özal Üniversitesi, Malatya, Türkiye bulent.akkoyun@ozal.edu.tr

ORCID: 0000-0003-4271-6974

Başvuru/Submitted: 4/11/2021

Revizyon/Revised: 7/12/2021

Kabul/Accepted: 12/12/2021

Yayın/Online Published: 25/12/2021

Atıf/Citation: Akkoyun, B., Bilişim teknolojileri kullanımının işletmelerde bilgi yönetimi süreci üzerine etkisi, bmij (2021) 9 (4): 1656-1672, doi: https://doi.org/10.15295/bmij.v9i4.1966
Öz

Çalışma, bilişim teknolojisi araçları kullanımının işletmelerde bilgi yönetimi sürecine etkisini incelemek ve açı̆̆a çıkartmak için yapılmıştır. Çalışma uygulamalı bir araştırma olup, istatistiksel teknikler sayesinde, hipotezlerde iddia edilen ilişkinin/etkinin gerçekliğini ispata çalışan, aynı zamanda sosyal durumları ve bu durum ile alakalı kavramların bağımlı ve bağımsız değişkenleri arasındaki ilişkiyi irdeleyerek kavramaya ve açıklamaya çalışan açıklayıcı/nedensel bir tasarım üzerine kuruludur. Nicel araştırma yöntemi ile gerçekleştirilen çalışma, Malatya'da organize sanayi bölgesinde faaliyet gösteren işletmelerde 441 çalışan üzerinde yapılmıștır. Çalışmada, personelin geneline ulaşmada sorunlarla karşılaşılabileceği ve birçok departman söz konusu olduğundan tabakalı örnekleme tekniği kullanılmıştır. Yüz yüze anket yöntemi ile ölçekler sayesinde sağlanan verilerin faktör ve güvenilirlik analizleri yapıldıktan sonra çoklu regresyon analizleri gerçekleştirilmiştir. SPSS analiz programılla yapılan analizlerden elde edilen sonuçlara göre işletmelerde organizasyonun hafızası, bilginin örgüt içerisinde paylaşımı ve dağılımı, bilginin elde edilmesi ve bilgiye karşı hassasiyet gibi bilgi yönetimi süreçleri ön plana çıkmıştır. Bununla birlikte, bağımsız değişken olan bilişim teknolojileri (BT) kullanımını oluşturan “bilginin kazanımı, Ar-Ge, bilginin ileti ve etkileşimi, fikrini aktarım yeteneği ile oyun-eğlence" faktörlerinin (boyutlarının), bağımlı değişken Bilgi Yönetimini oluşturan "örgütsel hafıza, bilgi paylaşımı, bilgi edinimi/kavramı ve bilgi duyarlılığı" faktörleri (boyutları) üzerinde farklı onarlarda ve önemli etkilerinin olduğu sonucuna ulaşılmıştır.

Anahtar Kelimeler: Bilişim Teknolojisi, Bilgi Yönetimi, İletişim, Örgütsel Hafıza, Bilgi Duyarlılı̆̆ı

Jel Kodlari: M10, M15, D83

\begin{abstract}
The study was conducted to examine and reveal the effect of information technology tools on the information management process in enterprises. The analysis is applied research. It tries to prove the effect claimed in the hypotheses by using statistical techniques. It also relies on an explanatory/causal pattern to understand and explain the relationship between dependent and independent variables. The study, which was carried out with the research method, was carried out on 441 employees in enterprises operating in the organized industrial zone in Malatya. In the study, a stratified sampling technique was used since there are many departments and many departments that may encounter problems in reaching the general staff. Multiple regression analyses were carried out after the factor and reliability analysis of the data provided by the scales with the face-to-face survey method. According to the results obtained from the analysis made with the SPSS analysis program, information management processes such as organizational memory, information sharing, information acquisition, information sensitivity have come to the fore. On the other hand, it was concluded that the information technologies dimensions (acquiring information, research-examination, communication, selfexpression, game-entertainment) that constitute the independent variables have significant effects on the dependent variables (organizational memory, information sharing, information acquisition, information sensitivity).
\end{abstract}

Keywords: Information Technology, Information Management, Communication, Organizational Memory, Information Sensitivity

Jel Codes: M10, M15, D83 


\section{Extended Abstract}

\section{Effect of the use of information technologies on the information management process in the business}

\section{Literature}

\section{Research subject}

The subject of the study is information technologies and the activities of the employees who will use the technology in the enterprises in transferring the information to the management process. Because, in today's intensely competitive environment, besides factors such as quality and time, it is essential to determine how data can be managed systematically and how businesses can gain a competitive advantage (Durna, 2008; Uzun, 2008: 33). It is thought that companies will achieve the best efficiency when information technologies and information management systems talent come together in the ideal conditions. The management of information is crucial for the people who manage these systems and the stakeholders of the relevant units. Because this information is the most important element of the business-like human and is vital for the future, therefore, information management and information technology systems will be more efficient in the harmony of the corporate culture that understands the necessity of this rather than being an utterly technology-based system (Karakoçak, 2007: 93-94).

\section{Research purpose and importance}

The study was conducted to examine and reveal the effect of information technology tools on the information management process in enterprises. Each period has its conveniences and difficulties in business administration and organisation processes. In this sense, the follow-up and acquisition of technological developments that will facilitate the management and employees' work have always maintained their importance. For this reason, it has been understood that traditional methods for businesses are no longer sufficient to meet the needs of the age, especially with the developments in information technologies and the transition to the information age. Therefore, systems that facilitate business life such as communication, information collection, data analysis, reporting and other management and information have become more critical day by day.

\section{Contribution of the article to the literature}

As a result of the research, it was determined that the dimensions of "acquiring information, research-examination, communication, self-expression and game-entertainment", which constitute the use of information technologies, have significant effects on the dependent variable (organizational memory, information sharing, information acquisition and information sensitivity). Therefore, the fact that different and essential effects on (dimensions) have been revealed constitutes the contribution of the study/article to the literature. Furthermore, the fact that other and actual effects on (dimensions) have been demonstrated includes the contribution of the study/article to the literature.

\section{Design and method}

\section{Research type}

The study is applied research and is based on an explanatory/causal design that tries to prove the reality of the relationship/effect claimed in the hypotheses and also tries to comprehend and explain the relationship between social situations and the dependent and independent variables of the concepts related to this situation, using statistical techniques.

\section{Research problems}

The research problem is, "Does the use of information technologies in businesses affect the information management process?" constitutes the problem. On the other hand, in line with the research model, we can state that the applied multiple linear regression can also be formulated as $(\hat{\mathrm{Y}}=\mathrm{a}+\mathrm{b} 1 \mathrm{X} 1+\mathrm{b} 2 \mathrm{X} 2+\ldots \ldots . .+\mathrm{bn} \mathrm{Xn})$.

\section{Data collection method}

The research universe consists of the managers and employees of the enterprises operating mainly in Malatya Organized Industrial Zones. In the study, the stratified sampling technique was used because the number of departments is high and there may be problems reaching all employees. Simple random sampling was applied among the sub-strata determined in proportion to the number of employees in each unit. In Özdamar's (2003) study, 385 questionnaires were used according to the data expressed with formulas and tabulated by Yazıcığlu and Erdoğan (2004). It is based on sampling errors at various values within the 5\% confidence interval. A time-lagged face-to-face survey was conducted for the targeted 500 personnel by being cautious to catch up (Lin, 1976). As a result of the questionnaire study applied to 441 people reached, primary data were included in the analysis. The questionnaires were administered in small groups and separately to avoid pressure and anxiety among staff. Ten questionnaires whose matching codes did not match in the questionnaires were not evaluated in the analysis. The sample-set was cleaned by including 421 questionnaires in the study. Thus, the error rate and data quality of the answers were tried to be preserved.

The " Using Information Technologies " scale is the first of the two scales used in the research, of which validity and reliability tests were carried out in previous studies, is the "Using Information Technologies" scale. The scale developed by Mustafa Özmusul (2011) consists of five dimensions. The reliability analysis result of the scale, which consists of information acquisition, researchexamination, communication, self-expression and game-entertainment dimensions, was expressed as 821 .

The second of the scales used in the research is the "Knowledge Management Tendency" scale. The knowledge management tendency scale was developed by Wang, Ahmed and Rafig (2008). The scale, adapted into Turkish and adapted by Durnali and Limon (2020), consists of organizational memory, knowledge sharing, knowledge acquisition/concept, and knowledge sensitivity. The reliability analysis result of the scale was expressed as 901 .

\section{Quantitative/qualitative analysis}

For the scales used in the research, factor and reliability analysis were performed using the SPSS program, which is a quantitative application. Afterwards, multiple linear regression analysis was performed to reveal the effect of the independent variable from multidimensional/factorial scales on the dependent variable. 


\section{Research model}

The model of the research is mathematically; $\hat{\mathrm{Y}}=\mathrm{a}+\mathrm{b} 1 \mathrm{X} 1+\mathrm{b} 2 \mathrm{X} 2+\ldots \ldots . .+\mathrm{bn} \mathrm{Xn}$.

\section{Research hypotheses}

We can express the primary and sub-hypotheses of the research as follows.

$\mathrm{H} 1=$ "The use of information technologies affects the information management process of enterprises".

$\mathrm{H} 1 \mathrm{a}=$ "The use of information technologies has an impact on the organizational memory of businesses."

$\mathrm{H} 1 \mathrm{~b}=$ "The use of information technologies has an impact on the knowledge sharing of business employees."

H1c = "The use of information technologies has an impact on the way employees obtain information."

H1d $=$ "The use of information technologies has an impact on the information sensitivity of business employees."

\section{Findings and discussion}

\section{Findings as a result of analysis}

As a result of the research, it was determined that the dimensions of "acquiring information, research-examination, communication, self-expression and game-entertainment", which constitute the use of information technologies, have significant effects on the dependent variable (organizational memory, information sharing, information acquisition and information sensitivity).

\section{Hypothesis test results}

$\mathrm{H} 1=$ Accept, $\mathrm{H} 1_{\mathrm{a}}=$ Accept, $\mathrm{H} 1_{\mathrm{b}}=$ Accept, $\mathrm{H} 1_{\mathrm{c}}=$ Accept, $\mathrm{H} 1_{\mathrm{d}}=$ Accept

\section{Discussing the findings with the literature}

With information technology tools, the practical and planned distribution of data by analyzing data to create the information needed by businesses is possible. Business information can be used by making interdepartmental associations in the long, medium and short term. With the best analysis of the relations between the departments, the processing efficiency will likely increase, and the business will gain a competitive advantage. Information technology tools are used effectively in many places, such as information reporting, storage, analysis, design, R\&D in enterprises (Dulkadir, 2021: 198).

\section{Conclusion, recommendation and limitations}

\section{Results of the article}

As a result of the research, all hypotheses regarding the study were accepted. Accepting the hypotheses shows that information management is done effectively and efficiently with information technology tools. To survive in a globalizing world and a highly competitive environment, information technology tools should be utilized in the best way and developments in this field should be followed meticulously. Because information technology systems, in which information is managed in the best way, continue to develop day by day in a dizzying way.

\section{Suggestions based on results}

Information technologies are strongly recommended for efficient and planned data distribution by analyzing them to provide the reports they need. Conversion of the stored data into information will be effective in the problems experienced in the past and in the solution proposals to be brought accordingly in a short time, thanks to the organizational memory and information technology tools they will activate. Information management can be done quickly by providing accessible communication with information technology tools. With the ease of information technology-based communication, the duration of all activities can be shortened and shared among employees more quickly and efficiently. Obtaining information can be achieved much more rapidly and in a short time with information technology tools such as mail, programs (ERP, Expert system etc.), communication groups. Since information management will become easier with information technology tools, it is recommended to apply information technologies in information management to businesses. In addition, it can be suggested to the academic world to work on the subject with other variables, especially with other disciplines such as industry 4.0 or artificial intelligence.

\section{Limitations of the article}

The research carried out also has its possible limitations, as with all research. The content and regulations of the study can be handled in various ways in terms of both its content and sample size and regional and sectoral factors. For example, when the study was considered from a regional point of view, it had to be limited to Malatya due to time and economic constraints. Likewise, due to the worrying effects of the pandemic on society in the field activities of the study, problems were encountered in the one-to-one implementation of the survey studies. 


\section{Giriş}

İşletmelerin en önemli temel kaynağı ve varlı̆̆ı olan çalışanlar, işletme içindeki tüm verileri alıp bunları uygun teknolojiler ile bilgiye çevirip kullanabilmektedir. İşletme faaliyetlerinin sürekliliği için bilgi en önemli unsur konumundadır. Özellikle rekabetin çok yoğun olduğu günümüzde işletmelerin gerçekleştirdikleri üretim/hizmet faaliyetlerini en kaliteli şekilde sunabilmek için bilgi yönetimi ve bilişim teknolojileri (BT) kavramı ön plana çıkmaktadır. Bilginin en iyi şekilde kullanılarak yönetilmesi bilişim teknolojisi sistemleri ile daha da mümkün olabilmektedir. Bilgi yönetimi, konuyla ilgili tüm verilerin toplanıp ilgili kişilere zamanında aktarılarak her yerden her zaman ulaşılmasını sağlamaktadır. Bu işlemlerin tamamı ise bilgiyi depolayıp analiz ederek kullanıma sunan bilişim teknolojisi sistemleri ile mümkün olmaktadır. BT ve bilgi yönetimi kavramlarının uygun koşullarda bir arada kullanılmasının işletmelere olumlu katkısının olacağı düşünülmektedir. Gelişmelere bağlı olarak işletmeler ayakta kalmak ve bunun sürekliliğini sağlamak için hem teknolojiyi takip etmek zorunda hem de kendisine yeni bilgi kaynakları bularak bunları en iyi şekilde bilişim teknolojisi sistemleri ile yönetmek durumundadır. Bu kavramları en iyi şekilde takip ederek güncelleyen ve yönetebilen işletmeler hedeflerine daha kolay ulaşabilmektedirler. Ayrıca, daha önce gerçekleştirilmiş araştırmalar incelendiğinde işletmelerin rekabet avantajına ulaşmasının yanında bilgi (Davila, Varvakis ve North, 2019; 243) ve bilginin işletme performansına kayda değer şekilde etki ettiğine dair birçok sonuç bulunmaktadır (Hussinki, Ritala, Vanhala and Kianto, 2017; 1478). Bilgi, işletmelerde inovasyon ve rekabet üstünlüğü konularında önemli bir kaynak olduğu için bilgi yönetim uygulamalarının geliştirilmesi ve sürdürülebilir olması adına bilişim sistemlerinden yararlanılması elzemdir.

Özellikle içinden geçtiğimiz zorlu pandemi döneminde işletmelerin ayakta kalarak yaşamlarını devam ettirebilmeleri adına dijital dönüşümlerine ağırlık vererek iş süreçlerini ve personel reformunu pazar ve dahası uzun zamandır devam eden ve ne kadar daha devam edeceği de belirsizliğini koruyan kriz ortamına göre şekillendirmeleri gerekmektedir. Bu durumda zorlu sürecin nasıl atlatılacağı ve bu duruma adaptasyonun ne şekilde sağlanacağı konusunda en değerli faktörün bilgi olduğu ve dönüşümün hızında bilişim teknolojilerinin doğru yönetilmesi hayati önem taşımaktadır.

Konu ile ilgili alan yazın tarandığında, bilişim teknolojileri kullanımının örgütlerdeki bilgi yönetimi sürecine etkisi üzerindeki çalışmaların yok denecek kadar az olması bu alanda yapılacak çalışmalara olan ihtiyacı göstermektedir. Araştırmada işletmelerdeki bilişim teknolojisi sistemlerinin bilgi yönetimi üzerindeki etkisi incelenmeye çalışılmışır. Yapılan analizler sonucu elde edilen bilgilerden yola çıkılarak bilişim teknolojisi sistemlerinin bilgi yönetimi sürecinde en iyi şekilde nasıl yönetileceği üzerinde öneriler geliştirilmiştir. Önerilerde bilginin üretilmesi, iletilmesi depolandığ noktadan kimlerin nasıl ve ne şekilde ulaşılabileceği ile ilgili konulara yer verilmiştir. Böylece bilginin en verimli şekilde kullanılmaya başlayarak maliyetlerin düşürülmesi ve işlerin en etkin şekilde gerçekleştirilebileceği ifade edilmiş ve bu sayede alandaki bir boşluk daha doldurulmaya çalışılmıştır.

\section{Literatür taramas1}

Çalışmanın bu kısmında, bilişim teknolojileri ve bilgi yönetimi ile ilgili literatürde yer alan temel bilgilere yer verildiği gibi bilgi yönetiminin işletmeler üzerindeki etkisi ve önemine ve buradan hareket ile işletmelerde bilişim teknolojilerinin bilgi yönetimi ile olan ilişkileri hakkındaki açıklamalara yer verilmiş ve araştırmada yer alan değişkenler arasındaki örüntü sağlanmaya çalışılmıştır.

\section{Bilişim teknolojileri}

İşletme alanında yönetim ve organizasyon süreçlerinde her dönemin kendine has kolaylık ve zorlukları bulunmaktadır. Bu anlamda yönetimin ve çalışanların işlerin kolaylaştıracak teknolojik gelişmelerin takibi ve edinimi her zaman önemini korumuştur. Bu sebeple özellikle bilişim teknolojilerinde yaşanan gelişmeler ve bilgi çağına geçiş ile birlikte işletmeler için geleneksel yöntemler artık dönemin ihtiyaçlarını karşılamada yetersiz kaldıklarından iletişim, bilgi toplama, veri analizi, raporlama ve diğer yönetim ve iş yaşamını kolaylaştıran bilişim sistemlerinin önemini her gün daha da artmaktadır.

Bilişim teknolojilerinden, işletmelerdeki pek çok sürecin her aşamasında yoğun olarak faydalanılmaktadır. BT ve faktörleri kimi zaman çalışanlarca süreçler içinde kullanılabildiği gibi, bazı durumlarda ise akıllı sistemler tarafından otomatik olarak kullanılmaktadır. Doğru bilgiye ulaşılarak analiz edilmesi bilgi sistemlerinin gereksinimlerini karşılayacak şekilde iyileştirilmesiyle mümkündür. $\mathrm{Bu}$ tür işlemler bilişim teknolojisi sistemleri ile kolayca tasarlanabilmektedir. BT hayatın pek çok alanında etkisini gösterdiği gibi, organizasyonlarda hatırı sayılır bir farklılık meydana getirmiştir. (Dulkadir, 2021: 194). Bununla birlikte, BT sistemlerindeki ilerlemeler, bir yandan kolaylık sağlarken diğer taraftan süreçleri daha karmaşık hale getirebilir. (Nuroğlu ve Tatoğlu, 2021: 108). Rekabetin 
olmazsa olmazı, yeni stratejilerin geliştirilerek işletmelerde uygulanabilmesi da BT ile birlikte daha kolay bir hale gelmiştir (Çetın, Şahın ve Yıldırım, 2010: 549).

BT, yatırımlarda daima dikkate alınan ve hizmet sektörünün bir dalı olan finans alanında sürekli bir arayış içerisindedir. Bu alan, sürekli gelişim halindeki teknoloji dünyasından en üst seviyede faydalanabilmek adına projeler üretip artan oranda yatırımlarını sürdürmektedirler. Her geçen gün yükselme trendindeki bilgi hacmi ve işlemlerin komplike hale gelmesiyle birlikte taleplere karşllık verme ve değişen koşullara hızla adapte olma, bilişim teknolojilerini tercih için ana nedenlerdir. Üst kalitede bir yönetim sisteminin esas olmasının yanında işletmelerin, zamanla kızışan rekabet koşullarında rakiplerinden geriye düşmemeleri ve hızlı değişen iş dünyasını analiz ederek adapte olabilmelerinde, bilişim teknolojilerinin payı diğer unsurlardan çok daha fazladır (Dönmez, 2007: 32).

Bilişim teknolojisi işgörenlerin iletişim tarzını da radikal bir şekilde değiştirmekle birlikte, onları, nerede bulundukları fark etmeksizin günde 24 saat, haftada 7 gün kesintisiz ulaşılabilir kılmıştır. Çalışanların takımı arkadaşları ile haberleşebilmeleri için, çalışma masasında yer alan donanımların yanında bulunma zorunlulukları ortadan kalkmıştır. Bilişim teknolojilerindeki bazı ilerlemelerin halihazırdaki yönetsel iletişim tarzı için önemli bir etkisinin bulunduğu ifade edilebilir. Bu ilerlemeler, "Ağ Tabanlı Bilgisayar Sistemleri", "Kablosuz İletişim İmkânları" ve "Bilgi Yönetim Sistemleridir" (Sezgin, 2019: 35). Diğer taraftan, bilişim teknolojileri iş ve yönetim alanında yeni bazı fırsatları ortaya çıkartmakla birlikte, dört unsur üzerinde (rekabet üstünlüğü sağlama, verimlilik ve performansı artırmada, organizasyonunda yeni iş geliştirmede) stratejik bir faktör olarak kullanılabileceği ifade edilmektedir. Bilişim teknolojilerinin jenerik stratejilerden verimliliğ̈in yukarı, maliyetlerin ise aşağı yönlü hareketinde, kaliteyi artırmada, organizasyonun iç ve dış iletişim sürecinin daha efektif olmasında fevkalade önemli bir faktör olduğu alan yazında çoğunlukla gündeme getirilmektedir. (Güleş, Bülbül ve Çağlayan, 2003: 65).

\section{Bilgi yönetimi}

Bilgi ve veri kavramları birbirinin yerine bazen ikame edilseler de farklılıklarına dikkat çekmek gerekir. Veri; durum, kanı veya direktiflerin, iletişim, açıklama ve faaliyet için müsait olarak sunumu olarak ifade edilirken (Türk Dil Kurumu, 2009), bilgi, kaidelerden yola çıkılarak kullanıcısının veriye yüklediği mana olarak ifade edilmektedir (Bal, 2010:5). Bilgi, durağan bir durumu değil hareketli bir durumu veya aksiyonu anlatır. Kişilerin var oldukları dünya ve varoluşa dair algılarının mana bulmasını sağlar (Blackler 1995: 1028-1029). Bir başka tanımda ise bilgi, akla yatkın bir yargı veya deneysel bir netice ileri süren, karşıdakilere veya muhataplara bir düzen dahilinde iletişim aracığıyla ulaştırılan vakalara ya da düşüncelere dair nizami bir yargı sistemi olarak geçmektedir (Bell,1973: 175).

İsmini bilgiden alan çă̆ımız bilginin ortaya koyduğu anlamın herkes tarafından uygun şekilde algılanmasından sonra, bilginin nasıl ve ne şekilde elde edildiğinin yanında bunun yöneticiler tarafından uygun şekilde kullanılması da bir o kadar önemlidir. Hızlı bir şekilde gelişen teknoloji bilginin analiz edilerek depolanması, iletilmesi, sınıflandırma yapması ve kullanıcılarına en uygun şekilde sunulması anlamında kolaylıklar sağlamıştır. Bu yapının oluşturularak işletmeler için önem arz etmesi ise yöneticilerin tecrübelerine bağlı olarak ne kadar başarılı olduklarına bağlıdır. Bundan dolayı bilgi yönetiminin işletmeler için önemi nedir sorusunu en net şekilde cevap bulabilmek için bilgi yönetimi kavramının en doğru şekilde tanımlanması gerekmektedir.

Bilgi Yönetimi, işletmenin kendi bünyesinde bulundurduğu ve işletme dışından sağlamış olduğu verileri en anlamlı şekilde sınıflandırıp, analiz eden, yorumlayan ve işletme süreçlerine dâhil eden bir sistemdir. Townley bilgi yönetimini, işletmenin varoluşunu gerçekleştirerek hedeflerine varmak için belirlediği planları olabildiğince etkili bir şekilde yerine getirmek adına bilgileri denetim ve kontrole tabi tutan faaliyetler olarak tanımlanmaktadır (Demirel ve Seçkin, 2008: 108). ABD Üretim ve Kalite Merkezi ise bilgi yönetimini, "Kullanılacak bilginin ortaya çıkıp fayda sağlaması için uygun zaman ve kişilere ulaşmasını sağlayan sistematik bir yaklaşımıdır" şeklinde tanımlamıştır (Buckman, 2004: 17). İşletmenin tüm çalışanlarında ki birikimleri de katarak veri tabanları, dokümantasyon belgeleri, politikalar ve prosedürleri de ihtiva eden organizasyonun toplam bilgi sermayesini saptamak, koordine etmek ve organizasyona yaymak ile ilgili birleştirilmiş belirli bir sistem dahilindeki yöntemdir. (Barquin, 2001:128-129). Bilgi yönetimi, işletmelerin entelektüel sermayesinin ayrılmaz bir unsuru olarak görülmektedir (Martensson, 2000:205). Bilgi yönetimi ile ilgili yapılan çalışmalarda; bilgi yönetim sürecinin başarılı olması için işletmenin yapısı, bilgi paylaşımına açık olan kültür yapısı, bilgi ve iletişim alt yapısı, personelin güçlendirilmesi ile tüm çalışanların bilgi yönetimine olan katkısı başlıca unsurlardandır. Bilgi yönetimi sisteminin kurulmasından uygulanması sürecine kadar tüm aşamalarda üst yönetimin desteği önem taşımaktadır (Karakoçak, 2007: 71). Bilgi yönetimi sürecinin aşamaları şekil 1' de detaylı olarak görülmektedir (Atak, 2011: 163). 


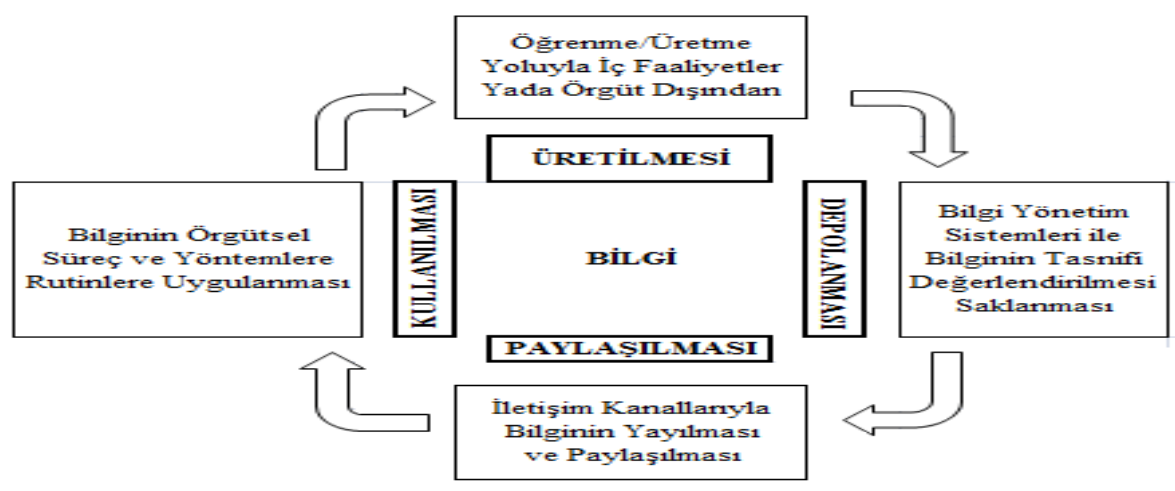

Şekil 1: Bilgi Yönetim Süreci

Kaynak: Atak, M. (2011), Örgütsel Bilginin Yönetimi ve Öğrenen Organizasyon Yazınındaki Yeri, İş̧ Güç Endüstri İlişkileri ve İnsan Kaynakları Dergisi,13 (2), 155-176.

\section{Bilgi yönetiminin işletmeler üzerindeki etkisi}

Günümüzde yoğun olan rekabet ortamında bilgi işletmeler için en önemli değer haline gelmiştir. Rekabet koşullarında işletmelere avantaj sağlayan bilgi ve yönetimi kavramı son zamanlarda üzerinden en çok durulması gereken konulardan birisi olmuştur. İşletmelerin en önemli varlığı çalışan kişilerin sahip olduğu bilgidir denilebilir. Bu gibi nedenlerden dolayı işletmeler normal sermayelerinin yanında insan sermayesine odaklanarak bilgi birikimlerini daha nasıl geliştirebileceklerinin üzerinde durmalıdır. Günümüz yoğun rekabet ortamında kalite, zaman gibi unsurların yanında bilginin belirli bir disiplin ile ne şeklide kullanılacağı ve böylece işletmelerin ne şekilde rekabet üstünlüğü sağlayacaklarının saptanması önemli bir problemdir (Durna ve Uzun, 2008: 33). Bilginin gelişmesi ve daha da önem kazanmasının yanında, organizasyonların temel sahipliklerinin içinde olan beşerî sermaye de önemli hale gelmiştir. İşletmelerin yükselme trendindeki zenginliği, bilgiden kaynaklanan beşerî sermayeyi elde etmekle benzer manayı ifade etmektedir (Stewart, 1997:37-78).

Küresel bir dünyada işletmesini geleceğe hazırlama çabaları içinde olan, rekabet avantajı sağlayarak devamlılığını sağlamaya çalışan organizasyonların dikkat etmeleri zorunda oldukları bir konu, organizasyonda ortaya çıkan ve diğer organizasyonlarca da taklit edilemeyecek olan bilgiyi en iyi şekilde yönetmektir. Bilgi yönetimin sağlamış olduğu faydaları direk onla ilişkilendirmek ve ne kadar fayda getirdiğini ölçmek zor bir iştir. Fakat bilgi sayesinde işletmelerdeki tüm birimlerde maliyetleri oluşturan etkenlerin hesaplanması ve deneyim gibi çoğu önemli konularda iyi bir göstergedir. Yapılan bu işlemler tam değilse de yakın bir ölçüde değerlendirilip izlenebilmektedir. Bilgi yönetiminin işletmeler açısından faydalarını aşağıdaki şekilde sıralayabiliriz (İraz, 2005: 248-249).

- İşletme için bir bellek oluşturarak tüm departmanlarda ki kritik bilgilerin kayıplarını önleyerek en iyi şekilde depolanarak korunmasını sağlar.

- Daha iyi ve etkin kararlar alınabilmesi için üst yönetime sunulacak olan bilginin kalitesini belirleyerek erişimi sağlamaktadır. Böylece üst yönetime giden bilgiler ile daha hızlı ve kaliteli kararlar alınarak alt kademelere iletilmektedir. Böylece çalışanların tümünün fonksiyonel gruplarda iyi bir motivasyon ile çalışarak morallerinin yüksek olmasına imkân sağlar

- İşletmenin mevcut ve potansiyel müşterilerini, nihai ürünleri ile pazar ve rakiplerini tam olarak anlamasına imkân sağlayarak konu ile ilgili fırsatların belirlenmesine yardımcı olmaktadır

- İşletmenin sahip olduğu mülkiyete kanuni korumanın sermayeye eklenmesi için organizasyonun becerilerini geliştirir.

- Ürün iyileştirme süreci ile işletmenin ürün ve hizmetlerine bilgi eklenmesine imkân sağlanarak ürünün müşteri tarafından bilinen değeri artmış olur.

- İşletmenin müşterilerine verdiği hizmetlere bağlı olarak müşteri kalitesini artırmaya ve odaklanmaya imkân sağlar.

- İşletmeler veritabanları ile elde ettikleri bilgiler yardımıla insan kaynakları yönetimini daha iyi bir şekilde yöneterek insan sermayesine olan yatırımın değerini artırır.

\section{İşletmelerde bilişim teknolojileri ve bilgi yönetimi ilişkisi}

BT sistemleri bilginin üretilmesi, farklı verilerden elde edilmesi ve kullanılmasında yararlanılan sistemler olarak ifade edilebilir. Bilişim teknolojilerine bu şekilde bakıldığında işletmeler için tüm bilgi sistemlerinin ve bilgi yönetimi sürecinin yapısını oluşturduğu görülmektedir. İyi bir bilgi yönetimi 
süreci için BT tek başına yeterli olmamaktadır. BT sayesinde veriler çok kolay bir şekilde bilgiye dönüştürülebilmektedir. Fakat bilginin üst yönetime sunulması için üst bilgiye dönüşümünde teknoloji yetersiz kalabilmektedir. Bilginin işlenip analiz edilerek yorumlanması ancak insanlar tarafından gerçekleştirilmektedir. Bu nedenden dolayı bilgi yönetimi için sistem tasarımı yapılırken insan talepleri ve düşünceleri kesinlikle dikkate alınmalıdır. Çünkü insan, konunun işletmeler üzerindeki etkisini görerek ya da tahmin ederek etkisini bilen kişi olarak nitelenebilir (Karagül, 2006: 37). BT günümüzde bütün işletmelerde yönetim adına stratejik bir unsur halini almış ve organizasyonlar rakiplerin küreselleşen rekabet ortamında, stratejik üstünlük sağlamak için bu teknolojilere ciddi yatırımlar yaparak gelişmeleri takip etmeye başlamışlardır (Earl, 1991: 5). Bilgi sistemleri, bilgisayar, telekomünikasyon ve iletişim teknolojilerinin yaygınlaşması ile bilgi yönetiminden umulan yararları maksimum seviyeye yükselten sistemler olarak da bilinirler. Anılan teknosistemlerin üstünlüklerini açığa çıkartarak, bilgilerin hızla üretilmesi, süratle paylaşılması ve bu sayede bilgi yönetimi süreci aktive edilerek sonuca daha da efektif ulaşılması sağlanır (Çağatay, 2008: 14). BT bir sistemin tamamını kapsamaktadır. BT sistemi çeşitli donanım araçlarından oluşan ve bu donanımlarda kullanılmak üzere geliştirilmiş olan özel programlar ve yazılımlar ile bilgi paylaşımını sağlayan bir kavram olarak tanımlanmaktadır. Tanımlardan da anlaşılacağı gibi BT sistemleri tek bir uygulamayı değil bütün uygulama ve sistemleri uyumlu olarak bir araya getirip işlevsellik sağlayan sistemlerdir (Yahyagil: 2001: 6-7). İşletmelerde bilgi ihtiyacı organizasyonun durumuna göre, üretim ve hizmet faaliyetlerine göre şekillenmektedir. İşletmelerde en uygun bilişim ağının kurulması bilgi ihtiyacının doğru yerde ve zamanda kullanılmasını sağlar (Carniero, 2000: 89). Bilgi ve teknoloji, kritik iş sahalarının daha iyi kontrol edebilmesine yardımcı entegrasyon hizmetleri de sunmaktadır (Şendurur ve Arslan, 2017: 27).

Bilgi yönetimi sistemleri günümüzde işletmelerin çoğunda mevcut olduğundan kendi içlerinde bir bilgi yönetimi sistemi geliştirmeleri mümkün olabilmektedir. Böylece bilgiye istenilen zamanda ve istenilen yerden ilgili kişilerce ulaşılabilmektedir. Bu şekilde bir durum için bilgi yönetimi sistemleri BT yardımıyla herkes için tüm işletme enformasyon sistemine bağlantı sağlar (Yıldırım, 2012: 50). Bilişim teknolojileriyle bilgi yönetimi sistemleri yeteneği en ideal şartlarda bir araya geldiğinde işletmelerin en iyi verime ulaşacağı muhtemeldir. Bu sistemleri yöneten kişiler ise verinin değerinin daha fazla farkındadır. Bilginin yönetilmesi ilgili birimlerin paydaşları kadar bu sistemleri yöneten kişiler içinde fazlasıyla önem taşımaktadır. Çünkü bu bilgiler işletmenin insan gibi en önemli unsuru olup gelecek açısından önem taşımaktadır. Dolayısıyla bilgi yönetimi ve bilişim teknolojisi sistemleri tamamen teknolojiye dayalı bir sistem olmaktan ziyade, bunun gerekliliğini anlayan kurum kültürünün uyumluluğunda daha verimli olacaktır (Karakoçak, 2007: 93-94).

\section{Metodoloji}

Araştırmanın bu kısmında, çalışmanın modeli ve modeline ait hipotezleri, evreni ve örneklemi, veri toplama araçları ve en önemlis de araştırma sonucu elde edilen verilerin analiz teknikleri ve sonuçları açıklanmaya çalışılmıştır.

\section{Araştırmanın model ve hipotezleri}

Yapılan açıklamalardan sonra araştırma sorunsalının “İşletmelerde BT kullanımı bilgi yönetimi sürecini etkiler mi?" olduğunu ve ayrıca açığa çıkan hipotezlerin yönlendirmesi altında araştırma modelinin de belirtildiği şekilde resmedilebileceği söylenebilir.

$\mathrm{H} 1=$ "BT kullanımı, işletmelerin bilgi yönetimi sürecini etkiler".

$\mathrm{H} 1 \mathrm{a}=$ "BT kullanımının, işletmelerin örgütsel hafızaları üzerinde etkisi vardır."

$\mathrm{H} 1 \mathrm{~b}=$ "BT kullanımının, işletme çalışanlarının bilgi paylaşımları üzerinde etkisi vardır"

$\mathrm{H} 1 \mathrm{c}=$ "BT kullanımının, çalışanların bilgi edinme şekilleri üzerinde etkisi vardır"

$\mathrm{H1d}=$ "Bilişim teknolojileri kullanımının, işletme çalışanlarının bilgi duyarlılıkları üzerinde etkisi vardir" 

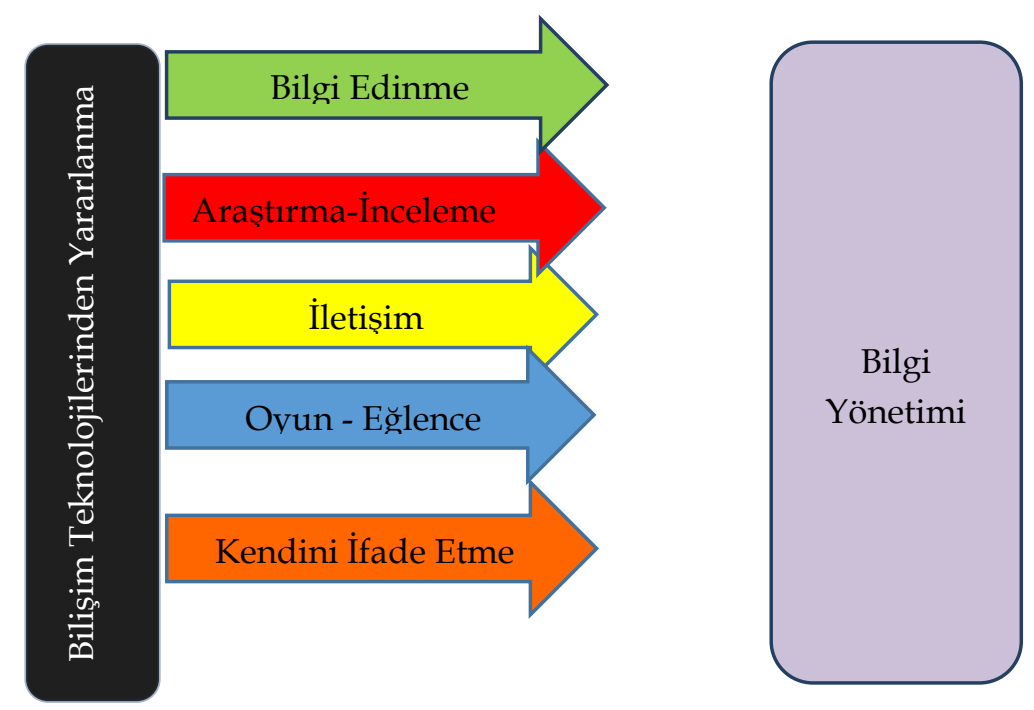

Şekil 2: Araştırma Modeli

Kaynak: Yazar tarafından üretilmiştir.

Diğer taraftan araştırma modeli doğrultusunda, uygulaması yapılan çoklu doğrusal regresyonun da ( $\hat{Y}$ $=\mathrm{a}+\mathrm{b} 1 \mathrm{X} 1+\mathrm{b} 2 \mathrm{X} 2+\ldots \ldots . .+\mathrm{bn} \mathrm{Xn})$ gibi formülize edilebileceği aktarılabilir.

Gerçekleştirilen çalışma için, Adıyaman Üniversitesi Sosyal ve Beşerî Bilimler Etik Kurulu'nun 11.02.2021 tarih ve 060 nolu kararı ile ihtiyaç duyulan "Etik Kurul" belgesi temin edilmiştir.

\section{Araştırmanın evreni ve örneklemi}

Gerçekleştirilen çalışmanın anakütlesi Malatya Organize Sanayi bölgelerinde ağırlıklı olarak faaliyette bulunan işletmelerin yönetici ve işgörenlerden oluşmaktadır. Personelin geneline ulaşmada sorunlarla karşılaşılabileceği ve birçok departman söz konusu olduğundan tabakalı örnekleme yöntemi uygulanmıştır. Her ünitenin işgören sayısı göz önünde bulundurularak bu sayılar nispetınde belirlenen alt katmanlar arasında basit rastlantısal temsil yoluna gidilmiştir. \%5 güven aralığında farklı rakamlarda temsil hatalarına göre gereklilik olan 385 deneği karşılayabilmek için tedbirli olarak amaçlanan 500 denek için farklı zamanlarda (Time Lagged) bire bir anket uygulamasının gerçekleştirilmesi hedeflenmiştir. Nihayetinde 441 işgören ile gerçekleştirilen anket uygulaması sonucunda, analizlerde ilk elden veriler kullanılmıştır. Stres ve kaygı hissetmemeleri adına işgörenler ile minimum 3'erli gruplar şeklinde gerçekleştirilen 441 anket arasından her değişken için farklı zamanlarda uygulanan anketlerin eşleşmesini sağlamak adına belirlenen kodlar ile eşleşmeyen 10 anket analizlerde değerlendirilmemiştir. Kalan ve çalışmaya alınan 421 örneklem setinin, cevaplardan kaynaklanan hatalardan temizlenmesi sağlanarak verinin niteliği korunmuştur.

\section{Veri toplama araçları}

Daha önce yapılan çalışmalarda geçerlik ve güvenirlikleri sınanmış olan ve çalışmada yer verilen ölçeklerden ilki "Bilişim Teknolojilerinden Yararlanma" ölçeğidir. Mustafa Özmusul (2011) tarafından geliştirilen ölçek beş faktörden oluşmaktadır. Bilgi edinim/kazanımı, Ar-Ge, bilginin iletişim/ileti ve etkileşimi, ifade/fikrini aktarım yeteneği ile oyun-eğlence faktörlerinden meydana gelen ölçeğin güvenilirlik test sonucu (Cronbach Alpha) 0,821 şeklindedir. Esasında daha güncel bir ölçek olmasına karşık tek boyuttan oluşması sebebiyle Asal ve Bayındır'ın (2019: 406) geliştirmiş ve kullanmış olduğu "Bilişim Teknolojileri Ölçeği" nden yararlanılmadığını da ifade etmek gerekmektedir.

Araştırmada kullanılan ölçeklerden ikincisi "Bilgi Yönetimi Eğilimi" ölçeğidir. Bilgi yönetimi eğilimi ölçeği Wang, Ahmed ve Rafig (2008) tarafından geliştirilmiştir. Türkçeye adaptasyonu ve uyarlaması Durnali ve Limon (2020) tarafından gerçekleştirilen ölçek, örgütsel hafıza, bilgi paylaşımı, bilgi edinimi/kavramı ve bilgi duyarlılığı olmak üzere dört boyuttan oluşmaktadır. Ölçeğin güvenilirlik analiz sonucu (Cronbach Alpha) 0,901 olarak ifade edilmiştir.

\section{Araştırma modelinde kullanılan değişkenlerin faktör analizi sonuçları}

Maddeler arası ilişki üzerinden, net ve kolay bir şekilde ifade edilmeye müsait ve aralarında fazla miktara ilişki barındıran maddeleri toparlayarak daha az faktöre indirgeyerek ifade edebilmesi, çalışmada ölçülecek olan değişkenin alt faktörlerini çeşitlendirerek ayrışması ve bağlı maddelerin, 
faktör değerlerine göre bağlı bulundukları değişkene tabi olarak gruplanması için geçerlilik çalışmaları doğrultusunda keşfedici faktör analizi (KFA) gerçekleştirilmiştir. Daha sonra bilişim teknolojilerinden yararlanma ölçeği için gerçekleştirilen faktör testinden ulaşılan "Açıklanan Toplam Varyans" ve "Topluluklar" tablolarına göre, teste tabi tutulan 18 madde için öz değeri geçerli sınırı aşan beş faktör altında toplandığı görülmüştür. Beş faktör hepsi birlikte ölçek için karşıladıkları varyans oranı \%72,272' dir. Maddeler halinde farklı şekilde gruplanan beş faktörün varyanslarının ise 0,578 ile 0,828 arasında değerler aldıkları ve testte açığa çıkan faktörler olarak şekillenen beş faktörün hepsi birden maddelerdeki toplam varyans ve ölçeğin tamamına dair varyansın çoğunluğunu açıladıkları görülmüştür.

"Component Matrix" sonuçlarına bakıldığında 18 madde arasından en zayıf faktör skorunun 0,578 ve yukarısında bir skorda olduğu görülmüştür. Bu netice, ölçeğin güçlü bir faktör örüntüsünde bulunduğunu ifade etmektedir. Döndürme uygulanmadan evvel ilk faktörün sahip olduğu varyansın \% 48,5 gibi bir değerde olması da iyi bir faktörel yapının belirdiğine işaret etmektedir.

Tablo 1. Bilişim Teknolojilerinden Yararlanma Ölçeği

\begin{tabular}{|c|c|c|c|c|c|}
\hline \multicolumn{2}{|c|}{ KMO: 0,938 } & \multirow{3}{*}{$\begin{array}{l}\text { Bilişim Teknolojilerinden Yararlanma Ölçeği } \\
\text { Maddeler }\end{array}$} & \multirow{3}{*}{$\begin{array}{l}\text { Yaklaşık } x^{2} \\
4590,747 \\
\text { Faktör Yükleri }\end{array}$} & \multirow{3}{*}{$\begin{array}{l}\text { SD } \\
153 \\
\text { Özdeğer }\end{array}$} & \multirow{3}{*}{$\begin{array}{l}\mathbf{p} \\
0,000 \\
\text { Açkl. Vry. \% }\end{array}$} \\
\hline & & & & & \\
\hline Faktör & Kod & & & & \\
\hline \multirow{5}{*}{ 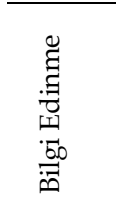 } & 1. Madde & & 0,764 & & \\
\hline & 2. Madde & & 0,827 & & \\
\hline & 3. Madde & & 0,771 & & \\
\hline & 4. Madde & & 0,724 & & \\
\hline & 5. Madde & & 0,602 & & \\
\hline \multirow{4}{*}{ 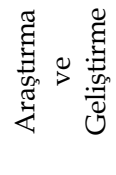 } & 6. Madde & & 0,794 & & \\
\hline & 7. Madde & & 0,729 & \multirow{2}{*}{2,412} & \multirow[b]{2}{*}{$8,, 302$} \\
\hline & 8. Madde & & 0,578 & & \\
\hline & 9. Madde & & 0,588 & \multirow{5}{*}{1,494} & \multirow{5}{*}{5,991} \\
\hline \multirow{4}{*}{ 芼 } & 10. Madde & & 0,737 & & \\
\hline & 11. Madde & & 0,771 & & \\
\hline & 12. Madde & & 0,698 & & \\
\hline & 13. Madde & & 0,673 & & \\
\hline \multirow{2}{*}{ 节 } & 14. Madde & & 0,791 & \multirow{2}{*}{1,192} & \multirow{2}{*}{4,957} \\
\hline & 15. Madde & & 0,828 & & \\
\hline \multirow{3}{*}{ 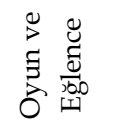 } & 16. Madde & & 0,788 & \multirow{3}{*}{1,078} & \multirow{3}{*}{4,508} \\
\hline & 17. Madde & & 0,743 & & \\
\hline & 18. Madde & & 0,777 & & \\
\hline
\end{tabular}

Kaynak: Yazar tarafından üretilmiştir.

Diğer taraftan "Bilgi Yönetimi Eğilimi" ölçeği için gerçekleştirilen faktör analizi sonucunda 16 maddenin dört faktör altında toplandığı görülmüştür. 
Tablo 2. Bilgi Yönetimi Ölçeği

\begin{tabular}{|c|c|c|c|c|c|}
\hline \multicolumn{2}{|c|}{ KMO: 0,914 } & \multirow{2}{*}{$\begin{array}{c}\text { Bilgi Yönetimi Ölçeği } \\
\text { Maddeler }\end{array}$} & \multirow{2}{*}{$\begin{array}{l}\text { Yaklaşık } \mathbf{x}^{2} \\
3282,075 \\
\text { Faktör Yükleri }\end{array}$} & \multirow{2}{*}{$\begin{array}{l}\text { SD } \\
120 \\
\text { Özdeğer }\end{array}$} & \multirow{2}{*}{$\begin{array}{l}\mathbf{p} \\
0,000 \\
\text { Açkl. Vry. \% }\end{array}$} \\
\hline Faktör & Kod & & & & \\
\hline \multirow{4}{*}{ 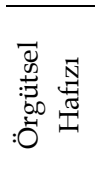 } & 19. Madde & & 0,749 & & \\
\hline & 20. Madde & & 0,736 & \multirow{3}{*}{7,218} & \multirow{3}{*}{45,110} \\
\hline & 21. Madde & & 0,675 & & \\
\hline & 22. Madde & & 0,600 & & \\
\hline \multirow{4}{*}{ 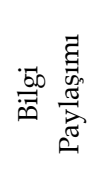 } & 23. Madde & & 0,745 & \multirow{4}{*}{1,259} & \multirow{4}{*}{$7,, 870$} \\
\hline & 24. Madde & & 0,769 & & \\
\hline & 25. Madde & & 0,734 & & \\
\hline & 26. Madde & & 0,600 & & \\
\hline \multirow{4}{*}{ कृ: } & 27. Madde & & 0,769 & \multirow{3}{*}{1,154} & \multirow{3}{*}{6,664} \\
\hline & 28. Madde & & 0,820 & & \\
\hline & 29. Madde & & 0,664 & & \\
\hline & 30. Madde & & 0,678 & \multirow{5}{*}{1,066} & \multirow{5}{*}{5,854} \\
\hline \multirow{4}{*}{ 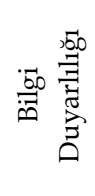 } & 31. Madde & & 0,639 & & \\
\hline & 32. Madde & & 0,757 & & \\
\hline & 33. Madde & & 0,742 & & \\
\hline & 34. Madde & & 0,696 & & \\
\hline
\end{tabular}

Kaynak: Yazar tarafından üretilmiştir.

Dört boyutun tamamının ölçek için tanımladıkları varyans sayısı \%65,498'dir. Maddeler şeklinde ayrı olarak gruplanan dört faktörün sahip oldukları varyanslarının ise 0,600 ve 0,820 arasında çeşitli değerlerde oldukları tespit edilmiştir.

\section{Araştırma modelinde yer alan değişkenlerin güvenilirlik analizi}

Araştırmada yer verilen her iki ölçeğin iç tutarlılığını sınamak adına ölçeklere ait faktörlerin iç tutarlılık skorlarına ulaşılmıştır. Ayrıca, çalışmaya ve ölçek maddelerine olan güven ile birlikte anketi cevaplayanların bu soruları ne kadar anladığını ifade etmede kullanılan Cronbach Alfa skorları ise gerekli olan sınırın $(0,7)$ fazlasıyla üstündedir.

Tablo 3. Bilişim Teknolojilerinden Yararlanma Ölçeği Güvenilirlik Analizi

\begin{tabular}{ll}
\hline Ölçekler ve Alt Boyutlar & Cronbach-Alpha \\
\hline Bilişim Teknolojilerinden Yararlanma (T) & 0,937 \\
Bilgi Edinme & 0,829 \\
Araştırma-İnceleme & 0,828 \\
İletişim & 0,838 \\
Kendini İfade Etme & 0,859 \\
Oyun-Eğlence & 0,838 \\
\hline
\end{tabular}

Kaynak: Yazar tarafından üretilmiştir.

Tablo 4. Bilgi Yönetimi Eğilimi Ölçeği Güvenilirlik Analizi

\begin{tabular}{ll}
\hline Ölçekler ve Alt Boyutlar & Cronbach-Alpha \\
\hline Bilgi Yönetimi Eğilimi (T) & 0,918 \\
Bilgi Paylaşımı & 0,793 \\
Bilgi Edinimi/Kavramı & 0,803 \\
Bilgi Duyarlılı̆̆ & 0,803 \\
\hline
\end{tabular}

Kaynak: Yazar tarafından üretilmiştir.

Bunun yanı sıra, ölçeklere dair maddelerin revize halindeki madde genel korelâsyon skorlarının tahminlenmiş sınır değerinin $(0,30)$ üstünde olduğu tespit edilmiştir. Bulgular ve değerler, ölçeklere ait iç tutarlılık testlerinin yeterli olduğunu göstermektedir.

\section{Bulgular}

Bağımsız değişkenler ile örgütsel hafıza bağımlı değişkeni arasındaki ikili ve kısmi ilişkiler (korelâsyonlar) incelendiğinde, bilgi edinme ile örgütsel hafıza arasında pozitif ve yüksek düzeyde $(r=0,702)$ bir ilişkinin olduğu, bununla birlikte diğer değişkenler kontrol edildiğinde iki değişken arasındaki korelasyonun $r=0,35$ olarak hesaplandığı görülmektedir. Araştırma-inceleme $(r=0,599)$, 
iletişim $(r=0,642)$, kendini ifade etme $(r=0,448)$ ve oyun-eğlenme $(r=0,561)$ ile örgütsel hafıza bağımlı değişken arasında ise orta düzeyde ve pozitif birer ilişki söz konusudur. Her bağımsız değişkenin kendisi dışında kalan değişkenler kontrol edildiğinde ise ilişkiler $r=, 30$ 'un altına düşük seviyelere indirgenmektedir.

Tablo 5. Örgütsel Hafıza Regresyon Analizi

\begin{tabular}{|c|c|c|c|c|c|c|c|}
\hline \multicolumn{8}{|c|}{ Cofficients $^{a}$} \\
\hline Değişken & B & Standart Hata & Beta & $\mathrm{T}$ & $\mathrm{p}$ & İkili r & Kısmi r \\
\hline org_haf (Sabit) & 0,686 & 0,144 & & 4,781 & 0,000 & & \\
\hline bil_edm & 0,338 & 0,043 & 0,382 & 7,806 & 0,000 & 0,702 & 0,354 \\
\hline ars_inc & 0,102 & 0,045 & 0,106 & 2,233 & 0,026 & 0,599 & 0,108 \\
\hline İletsm & 0,211 & 0,049 & 0,208 & 4,278 & 0,000 & 0,642 & 0,203 \\
\hline kn_if_et & 0,017 & 0,034 & 0,021 & 508 & 0,611 & 0,448 & 0,025 \\
\hline oyn_eglm & 0,145 & 0,038 & 0,168 & 3,809 & 0,000 & 0,561 & 0,182 \\
\hline \multicolumn{8}{|l|}{$\mathrm{R}=0,752 \quad \mathrm{R}^{2}=0,566$} \\
\hline$F_{(5,425)}=110,924$ & $\mathrm{P}=0,000$ & & & & & & \\
\hline
\end{tabular}

Kaynak: Yazar tarafından üretilmiştir.

Bilgi edinme, araştırma-geliştirme, iletişim, kendini ifade etme ve oyun-eğlenme değişkenleri birlikte, örgütsel hafıza puanları arasında orta seviyede ve anlamlı bir korelasyon bulunmaktadır. $\mathrm{R}=0,752$ $\mathrm{R} 2=0,566, \mathrm{p}<.01$. Ad1 geçen değişkenler hepsi birlikte örgütsel hafızadaki varyansın tamamının yaklaşık \%57'sini karşılamaktadır. Standart regresyon katsayısına $(\beta)^{\prime}$ ya göre, bağımsız parametrenin bağımlı parametre üzerindeki etkide önem sıralaması; bilgi edinme, iletişim, oyun-eğlenme, araştırma-inceleme ve kendini ifade etmedir.

Regresyon katsayılarına dair t-testi verilerine göre, kendini ifade etme değişkeni dışındaki bütün değişkenlerin örgütsel hafıza bağımlı değişkeni üzerinde anlamlı birer etki bıraktıkları görülmektedir.

Bu durumda BT kullanımının, işletmelerin örgütsel hafızaları üzerinde etkisinin olduğu belirtilebilir.

$\mathbf{H}_{1 \mathbf{a}}$ : Kabul

Çoklu doğrusal regresyon analizi sonuçlarına göre örgütsel hafızanın açıklanmasına veya tahminlenmesine ilişkin regresyon eşitliği;

Örgütsel Hafıza = 0,686 + 0,338bil_edm + 0,102ars_inc + 0,211iletsm + 0,017kn_if_et + 0,145 oyn_eglm

Diğer taraftan bağımsız değişkenler ile bilgi paylaşımı bağımlı değişkeni arasındaki ikili ve kısmi korelâsyonlar incelendiğinde ise, bilgi edinme $(\mathrm{r}=0,655)$, araştırma-inceleme $(\mathrm{r}=0,623)$, iletişim $(\mathrm{r}=0,654)$, kendini ifade etme $(r=0,457)$ ve oyun-eğlenme $(r=0,583)$ ile bilgi paylaşımı bağımlı değişkeni arasında orta düzeyde ve pozitif birer ilişki söz konusudur. Her bağımsız değişkenin kendisi dışında kalan diğer değişkenler kontrol edildiğinde ise ilişkiler $r=0,30$ ' un üzerinde olup, orta seviyelerde kalmaktadır.

Tablo 6. Bilgi Paylaşımı Regresyon Analizi

\begin{tabular}{|c|c|c|c|c|c|c|c|}
\hline Cofficients ${ }^{a}$ & & & & & & & \\
\hline Değişken & B & Standart Hata & Beta & T & $p$ & İkili $\mathrm{r}$ & Kismi r \\
\hline bil_pay (Sabit) & 0,579 & 0,145 & & 3,981 & 0,000 & & \\
\hline bil_edm & 0,220 & 0,044 & 0,247 & 5,025 & 0,000 & 0,655 & 0,427 \\
\hline ars_inc & 0,166 & 0,046 & 0,172 & 3,602 & 0,000 & 0,623 & 0,454 \\
\hline Iletsm & 0,259 & 0,050 & 0,254 & 5,188 & 0,000 & 0,654 & 0,433 \\
\hline kn_if_et & 0,014 & 0,035 & 0,016 & 0,394 & 0,694 & 0,457 & 0,608 \\
\hline oyn_eglm & 0,176 & 0,038 & 0,202 & 4,565 & 0,000 & 0,583 & 0,527 \\
\hline $\mathrm{R}=0,749 \quad \mathrm{R}^{2}=0,560$ & & & & & & & \\
\hline $\mathrm{F}_{(5,425)}=108,308$ & $\mathrm{P}=0,000$ & & & & & & \\
\hline
\end{tabular}

Kaynak: Yazar tarafından üretilmiştir.

Bilgi edinme, araştırma-geliştirme, iletişim, kendini ifade etme ve oyun-eğlenme değişkenleri birlikte, bilgi paylaşımı arasında orta seviyede ve anlamlı bir korelasyon bulunmaktadır. $R=0,749 \quad R 2=0,560$, $\mathrm{p}<.01$. Adı geçen değişkenler hepsi birlikte örgütsel hafızadaki varyansın tamamının yaklaşık \%56'sını karşılamaktadır. Standart regresyon katsayısına $(\beta)^{\prime}$ ya göre, bağımsız parametrenin bağımlı parametre 
üzerindeki etkide önem sıralaması; iletişim, bilgi edinme, oyun-eğlenme, araştırma-inceleme ve kendini ifade etmedir.

Regresyon katsayılarına dair t-testi verilerine göre, kendini ifade etme değişkeni dışındaki bütün değişkenlerin bilgi paylaşımı bağımlı değişkeni üzerinde anlamlı birer etki bıraktıkları görülmektedir.

Açıklananlar doğrultusunda BT kullanımının, işletme çalışanlarının bilgi paylaşımları üzerinde etkisinin olduğu ifade edilebilir.

$\mathbf{H}_{1 \mathrm{~b}}$ : Kabul

Çoklu doğrusal regresyon analizi sonuçlarına göre bilgi paylaşımı değişkeninin açıklanmasına veya tahminlenmesine ilişkin regresyon eşitliği;

Bilgi Paylaşımı $=0,579+0,220$ bil_edm $+0,166$ ars_inc $+0,259$ iletsm $+0,014 \mathrm{kn}$ if_et $+0,176$ oyn_eglm

Tablo 7: Bilgi Edinme Şekli Regresyon Analizi

\begin{tabular}{|c|c|c|c|c|c|c|c|}
\hline \multicolumn{8}{|l|}{ Cofficients ${ }^{a}$} \\
\hline Değişken & $B$ & Standart Hata & Beta & $T$ & $P$ & İkili r & Kismi r \\
\hline bil_edn (Sabit) & 0,727 & 0,162 & & 4,484 & 0,000 & & \\
\hline bil_edm & 0,196 & 0,049 & 0,216 & 4,012 & 0,000 & 0,591 & 0,191 \\
\hline ars_inc & 0,137 & 0,051 & 0,139 & 2,668 & 0,008 & 0,560 & 0,128 \\
\hline Iletsm & 0,255 & 0,056 & 0,244 & 4,569 & 0,000 & 0,605 & 0,216 \\
\hline kn_if_et & 0,176 & 0,039 & 0,204 & 4,528 & 0,000 & 0,514 & 0,215 \\
\hline oyn_eglm & 0,032 & 0,043 & 0,036 & 0,751 & 0,453 & 0,484 & 0,036 \\
\hline \multicolumn{8}{|l|}{$R=0,689 \quad R^{2}=0,475$} \\
\hline$F_{(5,425)}=76,997$ & $P=0,000$ & & & & & & \\
\hline
\end{tabular}

Kaynak: Yazar tarafından üretilmiştir.

Sonrasında bağımsız değişkenler ile bilgi edinimi bağımlı değişkeni arasındaki ikili ve kısmi korelâsyonlar incelendiğinde ise, bilgi edinme $(\mathrm{r}=0,591)$, araştırma-inceleme $(\mathrm{r}=0,560)$, iletişim $(\mathrm{r}=0,605)$, kendini ifade etme $(\mathrm{r}=0,514)$ ve oyun-eğlenme $(\mathrm{r}=0,484)$ ile bilgi edinimi bağımlı değişkeni arasında orta düzeyde ve pozitif birer ilişki söz konusudur. Her bağımsız değiş̧enin kendisi dışında kalan diğer değişkenler kontrol edildiğinde ise ilişkiler $r=0,30$ ' un altına düşük seviyelerde kalmaktadır.

Bilgi edinme, araştırma-geliştirme, iletişim, kendini ifade etme ve oyun-eğlenme değişkenleri birlikte, bilgi edinme arasında orta seviyede ve anlamlı bir korelasyon bulunmaktadır. $R=0,689 \quad R 2=0,475$, $\mathrm{p}<.01$. Adı geçen değişkenler hepsi birlikte bilgi edinme değişkenindeki varyansın tamamının yaklaşık $\% 47$ 'sini karşılamaktadır. Standart regresyon katsayısına $(\beta)^{\prime}$ ya göre, bağımsız parametrenin bağımlı parametre üzerindeki etkide önem sıralaması; iletişim, kendini ifade etme, bilgi edinme, araştırmainceleme ve oyun-eğlenmedir.

Regresyon katsayılarına dair t-testi verilerine göre, oyun-eğlenme değişkeni dışındaki bütün değişkenlerin bilgi paylaşımı bağımlı değişkeni üzerinde anlamlı birer etki bıraktıkları görülmektedir.

Bulguların sonucunda BT kullanımının, çalışanların bilgi edinme şekilleri üzerinde etkisinin olduğu belirtilebilir.

$\mathbf{H}_{1 \mathbf{c}}$ : Kabul

Çoklu doğrusal regresyon analizi sonuçlarına göre bilgi paylaşımı değişkeninin açıklanmasına veya tahminlenmesine ilişkin regresyon eşitliğini ise aşağıda olduğu gibi ifade edilebilir;

Bilgi Paylaşımı $=0,727+0,196$ bil_edm + 0,137ars_inc + 0,255iletsm + 0,176kn_if_et + 0,032 oyn_eglm

Son olarak bağımsız değişkenler ile bilgi duyarlılığı bağımlı değişkeni arasındaki ikili ve kısmi korelâsyonlar incelendiğinde, bilgi edinme ile örgütsel hafıza arasında pozitif ve yüksek düzeyde $(\mathrm{r}=0,756)$ bir ilişkinin olduğu, bununla birlikte diğer değişkenler kontrol edildiğinde iki değişken arasındaki korelâsyonun $\mathrm{r}=0,457$ olarak hesaplandığ 1 görülmektedir. Araştırma-inceleme $(\mathrm{r}=0,660)$, iletişim $(r=0,666)$, kendini ifade etme $(r=0,411)$ ve oyun-eğlenme $(r=0,610)$ ile bilgi duyarlılığı bağımlı değişken arasında ise orta düzeyde ve pozitif birer ilişki söz konusudur. Her bağımsız değişkenin kendisi dışında kalan değişkenler kontrol edildiğinde ise ilişkiler $r=0,30$ 'un altına düşük seviyelere inmektedir. 
Tablo 8: Bilgi Duyarlılığı Regresyon Analizi

\begin{tabular}{|c|c|c|c|c|c|c|c|}
\hline Cofficients $^{\mathrm{a}}$ & & & & & & & \\
\hline Değişken & $B$ & Standart Hata & Beta & $T$ & $\mathrm{p}$ & İkili $r$ & Kismi r \\
\hline bil_duy (Sabit) & 0,999 & 0,125 & & 8,021 & 0,000 & & \\
\hline bil_edm & 0,398 & 0,038 & 0,475 & 10,582 & 0,000 & 0,756 & 0,457 \\
\hline ars_inc & 0,196 & 0,039 & 0,217 & 4,979 & 0,000 & 0,660 & 0,235 \\
\hline Iletsm & 0,190 & 0,043 & 0,197 & 4,433 & 0,000 & 0,666 & 0,210 \\
\hline kn_if_et & 0,018 & 0,030 & 0,023 & 0,608 & 0,543 & 0,411 & 0,029 \\
\hline oyn_eglm & 0,017 & 0,033 & 0,021 & 0,511 & 0,610 & 0,497 & 0,025 \\
\hline $\mathrm{R}=0,797 \quad \mathrm{R}^{2}=0,635$ & & & & & & & \\
\hline$F_{(5,425)}=147,625$ & $\mathrm{P}=0,000$ & & & & & & \\
\hline
\end{tabular}

Kaynak: Yazar tarafından üretilmiştir.

Bilgi edinme, araştırma-geliştirme, iletişim, kendini ifade etme ve oyun-eğlenme değişkenleri birlikte, bilgi edinme arasında orta seviyede ve anlamlı bir korelasyon bulunmaktadır. $R=0,797 \quad R 2=0,635$, $\mathrm{p}<.01$. Adı geçen değişkenler hepsi birlikte bilgi edinme değişkenindeki varyansın tamamının yaklaşık \%63'ünü karşılamaktadır. Standart regresyon katsayısına ( $\beta)^{\prime}$ ya göre, bağımsız parametrenin bağımlı parametre üzerindeki etkide önem sıralaması; bilgi edinme, araştırma-inceleme, iletişim, kendini ifade etme, ve oyun-eğlenmedir.

Regresyon katsayılarına dair t-testi verilerine göre, kendini ifade etme ve oyun-eğlenme değişkenleri dışındaki bütün değişkenlerin bilgi duyarlılığı bağımlı değişkeni üzerinde anlamlı birer etki bıraktıkları görülmektedir.

Sonuç olarak BT kullanımının, işletme çalışanlarının bilgi duyarlılıkları üzerinde etkisinin bulunduğu aktarlabilir.

H1 $1_{\mathrm{d}}$ : Kabul

Çoklu doğrusal regresyon analizi sonuçlarına göre bilgi duyarlılı̆̆ı değişkeninin açıklanmasına veya tahminlenmesine ilişkin regresyon eşitliği ise;

Bilgi Duyarlılığ $=0,999+$ 0,398bil_edm + 0,196ars_inc + 0,190iletsm + 0,018kn_if_et + 0,017 oyn_eglm şeklinde olacaktır.

En nihayetinde bağımsız değişkenlerin bilgi yönetimi eğilimi değişkenine ait bütün alt boyutları üzerindeki belirgin etkilerinden yola çıkarak, BT kullanımının, işletmelerin bilgi yönetimi sürecini etkileyeceğini ifade ederek araştırmanın temel hipotezi sonuçlandırılabilir.

\section{$\mathrm{H}_{1}$ : Kabul}

\section{Tartışma sonuç ve öneriler}

Günümüz bilgi çağında işletmeler üretim/hizmet faaliyetlerini gerçekleştirirken iş süreçlerinde bilişim teknolojilerinden yararlanmaktadır. İşletmeler faaliyetlerine devam ederken kendi bünyesindeki ve dışarıdan aldıkları verileri işleyerek bilgi haline getirirler. Bilginin öneminin artmasıyla beraber bilişim teknolojisi araçları ile bilgi farklı şekillerde analiz edilerek en iyi şekilde yönetilebilmektedir. Çünkü işletmedeki farklı departmanlar arasındaki bilgi alışverişi sayesinde iş süreçlerinde kolaylıklar sağlanmaktadır. Bilgi yönetiminin amacı tüm iş süreçlerindeki bilgi akışının en uygun şekilde yerine getirilmesini sağlamaktır. Bu bağlamda bilişim teknolojisi araçlarının yardımıyla bilgi en iyi şekilde yönetilerek işletmelerin başarı ölçütlerinde olumlu katkılar sağlayabilir.

Yapılan araştırmada bilişim teknolojisi kullanımının bilgi yönetimi üzerindeki etkisinin boyutlarını belirlemek için faktör analizi yapılmıştır. Faktör analizi sonucunda bilginin edinim/kazanımı, Ar-Ge, bilginin iletişim/ileti ve etkileşimi, ifade/fikrini aktarım yeteneği ile oyun-eğlence şeklinde dört grup belirlenmiştir. Bilişim teknolojisi kullanımının bilgi yönetimi üzerindeki etkisini ölçmek amacıyla ana hipotezin yanı sıra dört adet alt hipotez oluşturulmuştur. Ana hipotez olan H1= "Bilişim teknolojileri kullanımı, işletmelerin bilgi yönetimi sürecini etkiler" hipotezi kabul görmüştür. İ̧̧letmelerin ihtiyaç duyduğu bilgilerin oluşturulması için verilerin analiz edilerek etkin ve planlı olarak dağıtılması bilişim teknolojisi araçları ile mümkün olmaktadır. İşletmeler bilgileri uzun, orta ve kısa vade de departmanlar arası ilişkilendirmeler yaparak kullanılabilmektedir. Departmanlar arasındaki ilişkilerin en iyi şekilde analiz edilmesiyle birlikte işlemenin verimliliğinin de artacağı muhtemel olup işletme rekabette üstünlük sağlayacaktır. Bilişim teknolojisi araçları ile işletmelerde bilgi raporlama, depolama, analiz 
etme, tasarım, ar-ge gibi birçok yerde etkin bir şekilde kullanılmaktadır. Alt hipotez olan H1a= "Bilişim teknolojileri kullanımının, işletmelerin örgütsel hafızaları üzerinde etkisi vardır" hipotezi kabul görmüştür. Örgütsel hafıza örgütlerin geçmişteki deneyim, tecrübe ve bilgilerinden faydalanarak geleceğe yön vermek için çizdiği bir yol haritası olarak tanımlanabilir. Örgüt geçmişteki deneyimlerinden öğrenerek bunu hafızasında kendince depolayarak şimdi ve gelecekte kullanabilecektir. İşletmelerde geçmişte yaşanan sorunlar ve buna göre kısa sürede getirilecek çözüm önerileri her açıdan önem taşımaktadır. Bu ise örgütsel hafıza ile mümkün olabilecektir. Örgütsel hafıza yine bilişim teknolojisi araçları ile depolanan verilerin bilgiye dönüştürülmesi ile mümkün olmaktadır. Alt hipotez olan $\mathrm{H} 1 \mathrm{~b}=$ "Bilişim teknolojileri kullanımının, işletme çalışanlarının bilgi paylaşımları üzerinde etkisi vardır" hipotezi kabul görmüştür. Bilişim teknolojisi araçları ile iletişim kolaylığı sağlanarak bilgi yönetimi çok kolay bir şekilde yapılabilmektedir. Bilişim teknolojisi tabanlı iletişim kolaylığı ile gerçekleştirilen tüm faaliyetlerin süresi kısaltılarak daha kolay ve verimli bir şekilde çalışanlar arasında paylaşılabilmektedir. Alt hipotez olan H1c= "Bilişim teknolojileri kullanımının, çalışanların bilgi edinme şekilleri üzerinde etkisi vardır" hipotezi kabul görmüştür. İşletmelerde çalışanlar farklı şekillerde bilgi edinebilmektedir. Her çalışan kendi departmanı ya da sorumlu olduğu birimin bilgilerine diğer birimlere göre daha kolay ulaşabilmektedir. Bilgi edinme mail, program (ERP, Uzman sistem vs.), iletişim grupları gibi bilişim teknolojisi araçları ile çok daha kolay ve kısa sürede gerçekleştirilebilmektedir. Bilişim teknolojisi araçları ile bilgi yönetimi daha kolay bir hale gelebilmektedir. Alt hipotez olan H1d= "Bilişim teknolojileri kullanımının, işletme çalışanlarının bilgi duyarlılıkları üzerinde etkisi vardır" hipotezi kabul görmüştür. Bilgi duyarlılığı bilginin doğruluk derecesine bağlı olarak faaliyetlere olan etkisi olarak tanımlanabilir. İşletme çalışanları işletme bilgilerine olan duyarlılıkları ile tüm üretim/hizmet faaliyetlerine yön vermektedir. Bu duyarlılı̆̆ı ise sağlayan yine bilişim teknolojisi araçları ile depolanan bilgilerdir.

Gerçekleştirilmiş olan çalışma ile paralellik arz eden diğer çalışmalardan McKisney G. Endüstri şirketinin (2012, 3), ABD Verimlik ve Kalite Çalışmaları Merkezi (1997), bilişim teknolojilerinin ve kullanımının bilgi çalışanları ve çalışanların bilgi yönetimi süreçleri üzerinde olumlu etkilerinin bulunduğu sonucuna ulaşmalarına karşın Sözbilir ve Yeşil (2013) yapmış oldukları çalışmalarında iki değişken arasında herhangi bir ilişki veya etkiye rastlayamamıştır. Aynı şekilde Sezgin de gerçekleştirmiş olduğu çalışmasında iki değişken arasında ilişki saptamıştır. Varışlı (2021; 425-427) çalışmasında bilişim teknolojileri kullanımına ait kişisel becerileri ortaya çıkarma boyutunun çalışanların motivasyonuna etki ettiğini tespit edilmiştir. Ayrıca, bilişim teknolojileri kullanımı boyutları olan teknolojiyi benimseme ve kişisel becerileri ortaya çıkarma boyutlarının, çalışanların motivasyonunda pozitif yönlü ve anlamlı bir fark olduğu tespit edilmiştir.

Bununla birlikte Durdu ve İpek'in (2020;113) bilişim teknolojileri ile rekabet üstünlüğü ile ilgili; Özer, Ciğerim ve Gök (2020; 4638-4640) ile Güleş vd.'nin (2003) ise çalışmalarında bilişim teknolojilerinin işletme performansı üzerinde olumlu etkilerinin bulunduğunu belirtilmişlerdir.

Sonuç olarak araştırma ile ilgili olarak tüm hipotezler kabul görmüştür. Hipotezlerin kabul görmesi bilgi yönetiminin bilişim teknolojisi araçları ile etkin ve kolay bir şekilde yapıldığını göstermektedir. Küreselleşen dünya ve rekabetin yüksek olduğu bir ortamda ayakta kalabilmek için bilişim teknolojisi araçlarından en iyi şekilde faydalanılmalı ve bu alandaki gelişmeler titiz bir şekilde takip edilmelidir. Çünkü bilginin en iyi şekilde yönetildiği bilişim teknolojisi sistemleri her geçen gün baş döndürücü bir şekilde gelişerek devam etmektedir.

İşletmelerin, ihtiyaç duydukları raporların temini için verilerin analiz edilerek etkin ve planlı olarak dağıtılması hususunda BT şiddetle önerilir. Geçmişte yaşanan sorunlar ve buna göre kısa sürede getirilecek çözüm önerilerinde aktive edecekleri örgütsel hafıza ile bilişim teknolojisi araçları sayesinde depolanan verilerin bilgiye dönüştürülmesi etkili olacaktır. Bilişim teknolojisi araçları ile iletişim kolaylığı sağlanarak bilgi yönetimi çok kolay bir şekilde yapılabilmektedir. Bilişim teknolojisi tabanlı iletişim kolaylığı ile gerçekleştirilen tüm faaliyetlerin süresi kısaltılarak daha kolay ve verimli bir şekilde çalışanlar arasında paylaşılabilmektedir. Bilgi edinme mail, program (ERP, Uzman sistem vs.), iletişim grupları gibi bilişim teknolojisi araçları ile çok daha kolay ve kısa sürede gerçekleştirilebilmektedir. Bilişim teknolojisi araçları ile bilgi yönetimi daha kolay bir hale geleceği için işletmelere bilgi yönetiminde BT uygulamaları önerilir. Bununla birlikte akademi dünyasına konuyu diğer değişkenler ile özellikle endüstri 4.0 veya yapay zekâ gibi diğer disiplinler ile ortak çalışmaları önerilebilir.

Bütün araştırmalarda olabileceği gibi gerçekleştirilmiş olan araştırtma da kendine özgü olası kısıtları barındırmaktadır. Çalışmanın içeriği ve kısıtları hem muhtevası ve örneklem dilimi hem de bölgesel ve sektörel faktörleri açısından çeşitli şekillerde ele alınabilir. Çalışma, bölgesel açıdan ele alındığında vakit engeli ve ekonomik kısıtlardan ötürü, Malatya ile sınırlandırılmak zorunda kalınmıştır. Aynı 
şekilde, çalışmanın alan aktiviteleri pandeminin toplum üzerindeki endişe uyandıran etkilerinden nedeniyle anket çalışmalarında bire bir uygulamada sorunlar ile karşılaşılmıştır.

\section{Hakem Değerlendirmesi / Peer-review:}

Dış bağımsız

Externally peer-reviewed

\section{Çıkar Çatışması / Conflict of interests:}

Yazar çıkar çatışması bildirmemiştir.

The author has no conflict of interest to declare.

\section{Finansal Destek / Grant Support:}

Yazar bu çalışma için finansal destek almadığını beyan etmiştir.

The author declared that this study has received no financial support.

\section{Etik Kurul Onayı / Ethics Committee Approval:}

$\mathrm{Bu}$ çalışma için etik kurul onayı, Adıyaman Üniversitesi, Sosyal ve Beşerî Bilimler Etik Kurulu/Komitesinden 11/02/2021 tarihli 2021-60 sayılı karar ile alınmıştır.

Ethics committee approval was received for this study from Adryaman University, Social Sciences and Humanities Ethics Committee on 11/02/2021 and 2021-60 document number.

\section{Kaynakça / References}

Asal, Ö. ve Bayındır, Y. (2019). Bilişim Teknolojileri Uygulamalarının Kurum Çalışanları Üzerindeki Etkileri: İzmit Belediyesi Örneği, Türkiye Sosyal Araştırmalar Dergisi, 23 (2), 401-412.

Atak, M. (2011), Örgütsel Bilginin Yönetimi ve Öğrenen Organizasyon Yazınındaki Yeri, İş Güç Endüstri İlişkileri ve İnsan Kaynakları Dergisi,13 (2), 155-176.

Bal, V. (2010). Bilgi Sistemlerinin Sağlık İşletmeleri Performansına Etkilerinin Veri Zarflama Analizi İle Ölçümü: Türkiye de' ki Devlet Hastanelerinde Bir Araştırma, Yayınlanmamış Doktora Tezi, Süleyman Demirel Üniversitesi, Sosyal Bilimler Enstitüsü, İşletme Anabilim Dalı, Isparta.

Barquan, R. C., (2001), What is Knowledge Management? Knowledge and Innovation: Journal of The KMCI.

Blackler, F. (1995), Knowledge, Knowledge Work and Organizations: An Overview and Interpretation, Organization Studies, 16 (6), 1021-1046.

Buckman, R. (2004). Building a Knowledge - Driven Organization, McGraw-Hill Companies Pub. USA

Carneiro, A. (2000), How Does Knowledge Management Influnce Innovation and Competitiveness?, Journal of Knowledge Management, 4 (2),.87-98.

Çetin, B., Şahın, L. ve Yıldırım K. (2010). “Biliş̧im Teknolojilerindeki Gelişmelerin İşletmelerin Strateji ve Maliyetleri Üzerindeki Etkileri", Sosyal Siyaset Konferansları Dergisi, 0, (56): 548-573.

Davila, G., Varvakis, G. and North, K. (2019). "Influence of Strategic Knowledge Management on Firm Innovativeness and Performance", Brazilian Business Review, 16 (3), 239- 254.

Demirel, Y. ve Seçkin, Z. (2008). Bilgi Yönetimi Uygulamasında etkili Olan Faktörler Üzerine Mobilyacılık Sektöründe Bir Araştırma, Zonguldak Karaelmas Üniversitesi, Sosyal Bilimler Enstitüsü Dergisi, 4 (8),107-122.

Dönmez, M. K. (2007). “İşletmelerde Bilişim Teknolojileri ve İşletme Performansı Üzerine Etkileri: Bişkekte Seyahat Acenteleri Üzerine Bir Uygulama", Yüksek Lisans Tezi, Kırgızıstan-Manas Üniversitesi Sosyal Bilimler Enstitüsü. 
Dulkadır, B. (2021). “Bilişim Teknolojisi Tabanlı Karar Destek Sistemleri İle İplik Üretim Tesislerinde Üretimin Planlanması" Alanya Akademik Bakış Dergisi (Alanya Academic Review Journal), 5, (1), ss.193-209. Doi: 10.29023/alanyaakademik.705424

Durdu, A. ve İpek, E. (2020). Bilgi Yönetiminin İşletmelere Yenilik ve Rekabet Üstünlüğü Sağlaması . AJIT-e: Bilişim Teknolojileri Online Dergisi , 11 (43) , 105-114

Durna, U. ve Uzun, H. (2008). İşletmelerde Rekabet Unsuru Olarak Bilgi Yönetimi, Niğde Üniversitesi, İktisadi ve İdari Bilimler Fakültesi Dergisi, 1 (1),33-43.

Durnali, M. ve Limon, İ. (2020). Bilgi Yönetimi Eğilimi Ölçeğinin Türkiye Kültürüne Uyarlanması: Geçerlik ve Güvenirlik Çalışması, Kastamonu Eğitim Dergisi, 28 (1), 95-106. DOI: 10.24106/kefdergi.3441

Earl, M. (1991), Information Management, The Strategic Dimension, Oxford University Press., N.York.

Güleş, H.K., Bülbül, H. ve Çağllyan V. (2003). "Bilişim Teknolojileri Kullanımının İşletme Performansına Etkisi: Küçük Ve Orta Ölçekli Sanayi İşletmelerinde Bir Uygulama", Süleyman Demirel Üniversitesi İïBF Sosyal ve Ekonomik Araştırmalar Dergisi 3, (1), ss. 61-83.

Hussinki, H., Ritala, P., Vanhala, M. ve Kianto, A. (2017). "Intellectual Capital, Knowledge Management Practices and Firm Performance", Journal of Ontellectual Capital, 18(4), 1469-1930.

İraz, R. (2005). İşletmelerde Bilgi Yönetiminin Yenilik ve Rekabet Gücü Üzerindeki Etkileri, Atatürk Üniversitesi, İktisadi ve İdari Bilimler Fakültesi, 19.(1) 243-258.

Karagül, A. A. (2006). Bilgi Yönetimi Sürecinde Kurumsal Kaynak Planlaması Uygulamalarının Muhasebe Bilgi Sistemine Etkisi ve Bir Uygulama, Yayınlanmamıs Doktora Tezi, Anadolu Üniversitesi, Sosyal Bilimler Enstitüsü, Eskişehir.

Karakoçak, K. (2007). Bilgi Yönetimi ve Verimliliğe Etkisi: Türkiye Büyük Millet Meclisi Uygulaması, Yayınlanmamış Doktora Tezi, Ankara Üniversitesi, Sosyal Bilimler Enstitüsü, İşletme Ana Bilim Dalı, Ankara.

Lin, N. (1976) Foundations of Social Research, McGraw-Hill, USA.

Martenson, M. (2000). A Critical Review of Knowledge Management as a Management Tool, Journal of Knowledge Management, 4, (3), 204-216.

Nuroğlu, H. ve Tatoğlu, E. (2021). “Bilişim Teknolojileri Kaynak ve Kapasitelerinin Kavramsallaştırılması Üzerine Sistematik Bir Literatür Araştırması", Uluslararası İktisadi ve İdari İncelemeler Dergisi (32): 107-124, Do1: 10.18092/Ulikidince.900398

Özdamar, K. (2003). Modern Bilimsel Araştırma Yöntemleri. Kaan Kitabevi, Eskişehir.

Özer G, Ciğerim E. ve Gök M. Ş (2020). Entelektüel Sermaye Ve Bilgi Yönetimi Stratejilerinin Firma Performansina Etkisi. Business and Management Studies: An International Journal, 8(5), 4611 - 4645.

Özmusul, M. (2011). Scale Development for The Utilization Of Information And Communication Technologies. Journal of Theoretical Educational Science , 4 (1) , 1-17.

Sezgın, İ. (2019). "Bilişim Teknolojileri Yeterliğinin İşletmelerin Bilgi Yönetimi Üzerindeki Etkisi”, Yüksek Lisans Tezi İstanbul Üniversitesi Sosyal Bilimler Enstitüsü.

Sözbilir, F. ve Yeşil, S. (2015). Bilişim Teknolojileri Yeterliğinin Bilgi Yönetimi Üzerindeki Etkisi: Türkiye'de Bir Alan Araştırması, Yönetim ve Ekonomi Araştırmaları Dergisi, 13(3), 18- 39.

Stewart, T. A. (1997), Entelektüel Sermaye, (Çev. Nurettin Elhüseyni), BDZ Yayıncılık, İstanbul.

Şendurur, P. ve Arslan, S. (2017). Eğitimde Teknoloji Entegrasyonunu Etkileyen Faktörlerdeki Değişim, Mehmet Akif Ersoy Üniversitesi Eğitim Fakültesi Dergisi, 0(43), 25-50.

Varışlı, N. (2021). İşletmelerde Bilgi Teknolojileri Kullanımının Çalışanların Motivasyonu Üzerine Etkisi: Kobiler Üzerinde Bir İnceleme, İşletme Araştırmaları Dergisi, 13 (1), 410-429.

Wang, C. L., Ahmed, P. K., and Rafig, M. (2008), Knowledge Management Orientation: Construct Development and Empirical Validation, European Journal of Information Systems, 17 (3), 219-235.

Yahyagil, M. Y. (2001). KOBİ'lerde Bilgisayar Teknolojileri Uygulamaları, İTO Yayın No:2001-26, İstanbul. 
Yazıcıoğlu, Y. ve Erdeoğan, S. (2004). Spss Uygulamalı Bilimsel Araştırma Yöntemleri, Detay Yayıncılık, Ankara.

Yıldırım, E. (2012). Müşteri İlişkileri Yönetiminde Bilgi Yönetimi ve Teknoloji Desteği ile CRM Analizi, YLT, Haliç Üniversitesi, Sosyal bilimler Enstitüsü, İşletme Ana Bilim Dalı, İşletme Programı, İstanbul. 